\title{
DESIGN AND ANALYSIS OF INLINE PIPE TURBINE
}

Muhammad Talha

Student, Department of Mechatronics Engineering, SZABIST, (Pakistan). E-mail: talhapacifer@gmail.com ORCID: https://orcid.org/0000-0003-4369-2388

Atif Saeed

Faculty, Department of Mechatronics Engineering, SZABIST, (Pakistan). E-mail: m.atif@szabist.edu.pk ORCID: https://orcid.org/0000-0003-1551-4314

Mustafa Jaffer

Student, Department of Mechatronics Engineering, SZABIST, (Pakistan). E-mail: mustafa.jafferxp@gmail.com ORCID: https://orcid.org/0000-0001-8364-8619

Hayyan Yousuf Khan

Student, Department of Mechatronics Engineering, SZABIST, (Pakistan). E-mail: hayyankhan1@live.com ORCID: https://orcid.org/0000-0002-4441-6863

Ali Haider

Student, Department of Mechatronics Engineering, SZABIST, (Pakistan). E-mail: alihyder10005.ah@gmail.com ORCID: https://orcid.org/0000-0003-4961-4882

Wajahat Ali

Student, Department of Mechanical Engineering, QUEST, (Pakistan). E-mail: wajahatqureshi281@gmail.com ORCID: https://orcid.org/0000-0003-3345-6461

\section{Citación sugerida Suggested citation}

Talha, M., Saeed, A., Jaffer, M., Khan, H. Y., Haider, A., y Ali, W. (2020). Design and analysis of inline pipe turbine. 3C Tecnología. Glosas de innovación aplicadas a la pyme. Edición Especial, Abril 2020, 6373. http://doi.org/10.17993/3ctecno.2020.specialissue5.63-73 


\section{ABSTRACT}

In this current smart era, electricity is considered a necessity for development as almost all of machinery and circuitry runs on electrical power. Therefore, the production of electricity is a must for attaining progress. But nowadays, there is a constant struggle for access to large fossil reservoirs and the development for renewable resources is slow. There have been innovative inventions such as the wind turbines, water turbines, solar cells and many other renewable sources. These resources have slowed down the depletion of fossil fuels to a certain extent, but these inventions do have their shortcomings and most areas where energy harnessing is possible, are left unanswered. One such area where energy conversion is possible is in the water transportation system. To harness electrical energy from this system, a small turbine generator can be installed onto the pipelines to harness the kinetic energy of the flowing water in them. Hence forth by applying this research, another renewable energy resource is developed.

\section{KEYWORDS}

Electricity, Pipe turbine, Design, Joint resistance. 


\section{INTRODUCTION AND LITERATURE REVIEW}

In the continuous growth of technology and society, many issues rise from the demands of progress. Some refer to the changes in climate due to pollution, to the shear lack of utilities. One such problem that we are still currently facing is the shortage of electricity. The world is in thorough search for renewable resources of electrical energy, and there has been substantial increase in green energy but with many shortcomings. Among these renewable resources are tidal generators, solar cells, wind turbines, geothermal generators and water turbines. But the shortcomings are that these resources are dependent on multiple factors such as lack of proper reservoir spacing for dams, weather anomalies, time dependencies of solar generators and tide dependencies of wave generators. Although these problems can be reduced to a minimum, other dependencies will still exist. Therefore we are constructing this project to further reduce the generated loses within mainly household and infrastructures. One such area where energy loses are not being addressed to, is found within the water transportation systems. These systems are in fact powered by the green energy projects such as dams, but the outcome of its use is still quite usable. Another place where the energy loses are not addressed is the water pipelines in houses and buildings which require an electric motor to pump water around multiple parts of the area (Breeze, 2005; Sthel, Tostes, \& Tavares, 2013; Das, 2015; Junejo, Saeed, \& Hameed, 2018). The flowing water in these lines runs at a high velocity at downward bends. Our solution to this problem is to install a small turbine with correspondence to the cross sectional area of the pipe (Lamfon, Najjar, \& Akyurt, 1998: Hajmohammadi et al., 2013; Samora et al., 2016).

The water turbine is one of the key technologies used in producing green energy which is beneficial to both, the environment and the society. The turbine uses the flow of water to generate electricity. The design of the turbine is such that when water encounters the blade, the turbine begins to rotate. The continuous force exerted by the water allows the turbine at a tremendously high amount of speed. This rotation is then utilized by a generator, whose rotating shaft is connected to the center of the turbine. Due to this connection the rotary mechanical movement of the turbine is transformed into electrical energy which is used to provide power to other areas. This turbine is only used as generating tools within large reservoirs, but other running water systems are still unaddressed hence there is a loss of 
kinetic energy which can be utilized by transforming it into electrical energy (Bauer, Marx, \& Drück, 2014; Saeed et al., 2018a; Saeed et al, 2018b).

The utilization of this flow of water is essential, therefore projects over how it can be done is not uncommon. There have been many experimentations of in-pipe water turbine therefore we are taking reference from the research of Oladosu and Koya (2018) from the Department of Mechanical engineering at Obafemi Awolowa University, Nigeria. Their research provided us with ample numerical data on the flow within pipes showing us the coordinates of maximum flow velocity, which is located at the center point of the pipe's diameter. Another research of Jiyun et al. (2018) of The Hong Kong Polytechnic University, China, has also been taken into consideration. This research describes the optimal turbine design for the highest efficiency. In their research, they have performed a simulation using a generator connected to a DN-100T-joint turbine to gather energy when placed inside a horizontal pipe in a vertical manner. The blade designs are shown to be more cup-shaped to allow contact with a larger volume of water. The results show that the turbine is giving a maximum efficiency of 55\% upon nozzle adjustments. Another inspiration for our design is accredited to the research of Joel Titus and Bakthavatsalam of the National Institute of Technology, Tiruchirappalli, India. Their semi-submerged design is considerably easier to construct and install in remote locations and is extremely viable in irrigation systems (Jiyun, 2017). However their simplistic design the turbine itself hinders the efficiency of energy production. By further widening and cupping the blades of the turbine, a larger volume of water can encounter the blades thus giving a higher angular acceleration and producing more electrical power. The research performs by Jiyun et al. (2018) of The Hong Kong Polytechnic University has also helped in designing our project. Their work on the outer angle of the turbine blade shows that the blade must be curved enough so that the inner wall of the turbine blade is parallel to the flow of water, but the outer wall of the blade does not receive first contact with the flowing water. This will allow the water to apply a larger force onto the blade of the turbine while decreasing the velocity of the water for short period of time to allow the other blade to sink into the water. 


\section{METHODOLOGY}

We have divided this research into three phases:

\section{Designing}

2. Construction

\section{Testing}

For the designing phase, we make our design on the SolidWorks software. On it we created the parts necessary for the construction of the turbine. We created a metal disk of thickness 0.5 inches and a diameter of 6 inches. We then constructed the spoon for the turbine. The outer diameter of the cup of the spoons is of 0.47 inches whereas the inner diameter is of 0.4 inches. These spoons will act as the blades of the turbine and the cup of these spoons will be placed at the center of the pipe where the fluid velocity is at its highest. The two parts, disk and spoons are then assembled together after the spacing for the spoons is cut into the turbine disk. We then constructed and attached a shaft of 0.3 inches diameter into the center of the turbine disk. This shaft is a part of the DC output motor that will be connected to the turbine for electricity production. We then created a prototype pipeline of three parts which's center piece is cut halfway. We then placed the turbine on to the pipeline accordingly in the assembly. Finally, we then constructed a cover box for the turbine so that water may not leak from the system out into the surrounding.

For the construction phase, we decided on using a thin metal sheet for the disk because if turbine becomes too heavy, much larger force will be required to rotate the turbine at high speed, thus hampering the efficiency of the output. This sheet is then mechanically cut into a circular shape of a diameter 6 inches. Small cuts for the joining of the spoons are applied onto the metallic disk at $45^{\circ}$ intervals.

For the testing phase we will apply a certain amount of external loading through simulations using SolidWorks onto the cup of the spoon while keeping the handle of the spoon fixed as it will be joined with the turbine disk. By applying a distributed loading on the cup of the spoon we can mimic the effects of the water pressure exerted onto the spoon. Motion analysis of the assembly will also be performed on the software to understand the movement output of the assembled turbine (Song, Ni, \& Tan, 2011). 


\section{ANALYSIS AND OBSERVATION}

Wireless by performing static analysis on the spoon using SolidWorks, we observe that the highest amount of stress is acting on the area between the cup and handle due to which there will be a small amount of displacement of the cup hence giving a low factor of safety of the entire spoon. However, since this is a static analysis, the rotatory motion of the turbine disk has not been considered. If the rotation of the turbine would be considered, the stress on the critical region of the spoon would substantially decrease therefore a higher factor of safety can be attained without the requirement of a stronger and more expensive material.

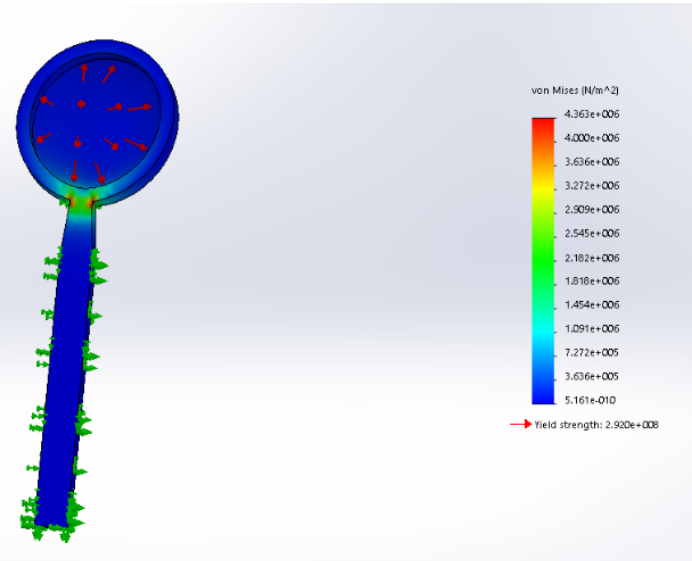

Figure 1. Stress Diagram.
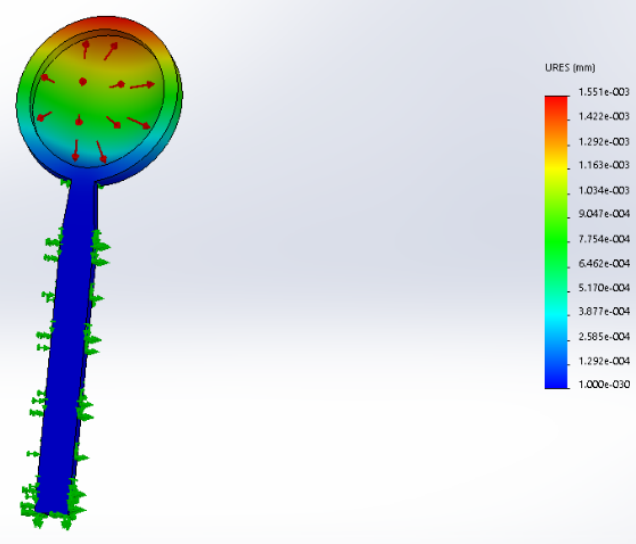

Figure 2. Strain Diagram. 

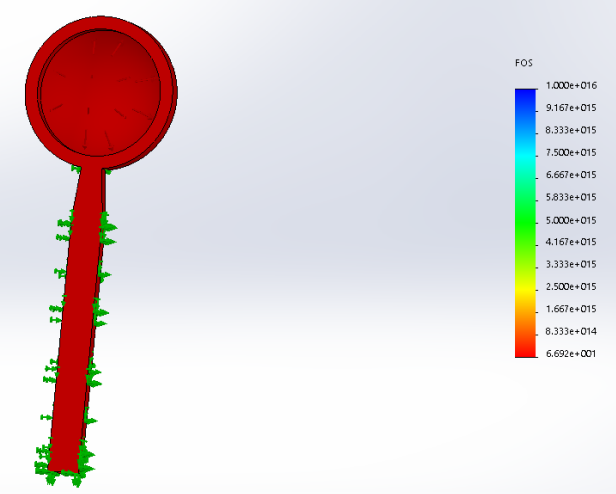

Figure 3. Factor-of-Safety Diagram.

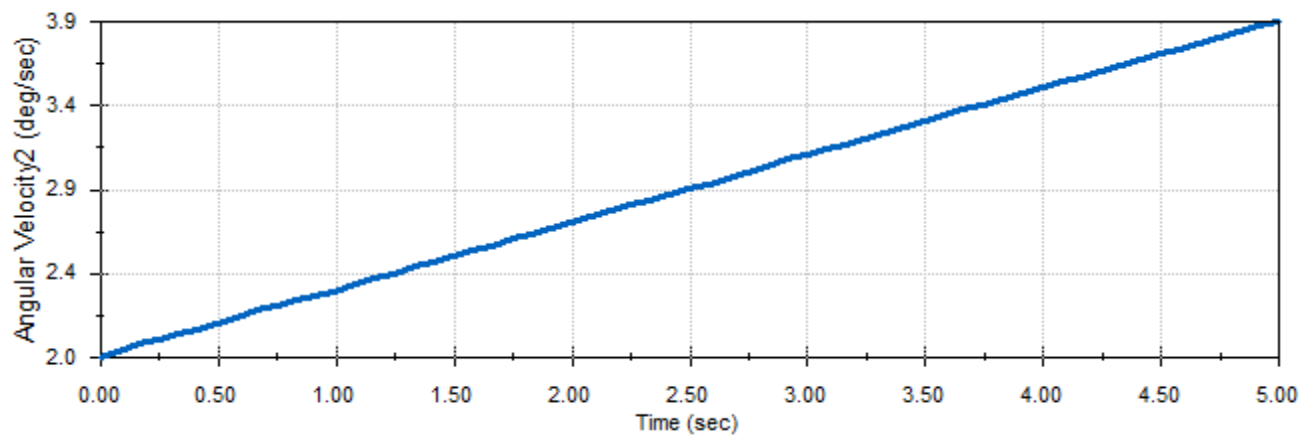

Figure 4. Angular velocity against time.

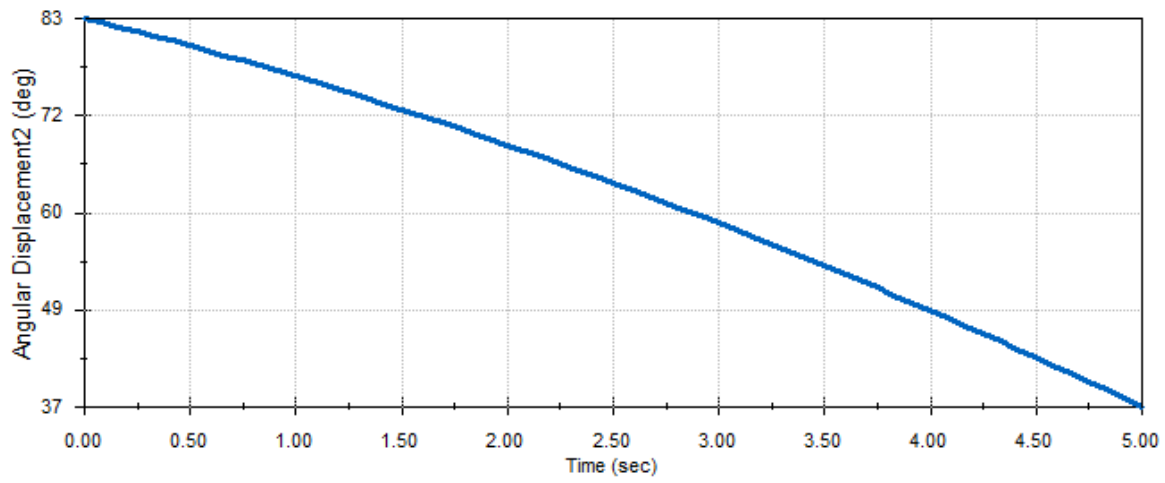

Figure 5. Angular displacement against time. 


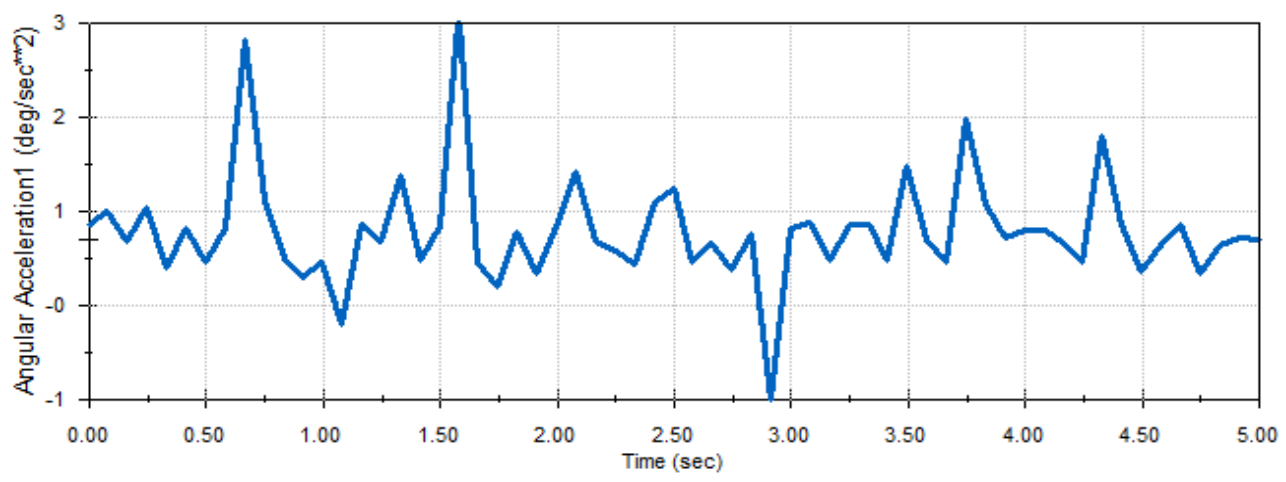

Figure 6. Angular acceleration against time.

The angular acceleration graph of the turbine displays ecstatic as there is a small amount of resistance in the joints of the cover therefore there is a reverse acceleration. This resistance may be due to the changes in the applied pressure of the water flowing within the pipes or if the spoon is touching the edges of the wall.

\section{CONCLUSION}

The turbine shows a good amount of electrical output but can further be improved if the joint resistance is addressed by adding a ball bearing that will increase the motion. A better design of the turbine can also be achieved by fully submerging the turbine instead of partial submersion without the detriment of ease in installation and maintenance.

The design can further be implemented on other flowing bodies of water such as rivers and canals by increasing and decreasing the size respectively of the turbine as this design can be applied over multiple flowing bodies of water.

\section{REFERENCES}

Bauer, D., Marx, R., \& Drück, H. (2014). Solar District Heating for the Built EnvironmentTechnology and Future Trends within the European Project EINSTEIN. Energy Procedia, 57, 2716-2724. https://doi.org/10.1016/j.egypro.2014.10.303

Breeze, P. (2005). Power Generation Technologies. Elsevier. https://doi.org/10.1016/C20120-00136-6 
Das, G. (2015). Advantages of green technology. International fournal of Research - GRANTHAALAYAH, 3(9), 1-5. https://www.researchgate.net/ publication/306402862_ADVANTAGES_OF_GREEN_TEGHNOLOGY

Hajmohammadi, M. R., Eskandari, H., Saffar-Awal, M., \& Campo, A. (2013). A new configuration of bend tubes for compound optimization of heat and fluid flow. Energy, 62, 418-424. https://doi.org/10.1016/j.energy.2013.09.046

Jiyun, D., Hongxing, Y., Zhicheng, S., \& Xiadong, G. (2017). Micro hydro power generation from water supply system in high rise buildings using pump as turbines. Energy, 137, 431-440. https://doi.org/10.1016/j.energy.2017.03.023

Jiyun, D., Hongxing, Y., Zhicheng, S., \& Xiadong, G. (2018). Development of an inline vertical cross-flow turbine for hydropower harvesting in urban water supply pipes. Renewable Energy, 127. https://doi.org/10.1016/j.renene.2018.04.070

Junejo, F., Saeed, A., \& Hameed, S. (2018). 5.19 Energy Management in Ocean Energy Systems. Comprehensive Energy Systems, 5, 778-807. https://doi.org/10.1016/B978-012-809597-3.00539-3

Lamfon, N. J., Najjar, Y. S. H., \& Akyurt, M. (1998). Modeling and simulation of combined gas turbine engine and heat pipe system for waste heat recovery and utilization. Energy Conversion and Management, 39(1-2), 81-86. https:/ / doi.org/10.1016/ S0196-8904(96)00175-6

Oladosu, T. L., \& Koya, O, A. (2018). Numerical analysis of lift-based in-pipe turbine for predicting hydropower harnessing potential in selected water distribution networks for waterlines optimization. Engineering Science and Technology, an International Fournal, 21(4),672-678. https://doi.org/10.1016/j.jestch.2018.05.016

Saeed, A., Mithaiwala, H. M., Hussain, A. I., Kukda, M. F., \& Shoukat, M. H. (2018a). Enhancement of Efficiency through optimization of flywheel. In 7th International Conference on Renewable Energy Research and Applications (ICRERA), 124-129. https://doi.org/10.1109/ICRERA.2018.8566986 
Saeed, A., Zubair, M., Khan, F. A., Mairaj, F., Siddique, M., \& Shiwanli, A. (2018b). Energy Savings through Ammonia Based Absorption Chiller System: A proposed Strategy. In 7th International Conference on Renewable Energy Research and Applications (ICRERA), 168-173. https://doi.org/10.1109/ICRERA.2018.8566805

Samora, I., Hasmatuchi, V., Münch-Alligné, G., Franca, M. J., Schleiss, A. J., \& Ramos, H. M. (2016). Experimental characterization of a five blade tubular propeller turbine for pipe inline installation. Renewable Energy, 95, 356-366. https:// doi.org/10.1016/j.renene.2016.04.023

Song, F., Ni, Y., \& Tan, Z. (2011). Optimization design,modeling and dynamic analysis for composite wind turbine blade. Procedia Engineering, 16, 369-375. https://doi. org/10.1016/j.proeng.2011.08.1097

Sthel, M., Tostes,J. G. R., \& Tavares,J. R. (2013). Current energy crisis and its economic and environmental consequences: Intense human cooperation. Natural Science, 05(02), 244-252. https://www.researchgate.net/publication/276492317_Current_energy_ crisis_and_its_economic_and_environmental_consequences_Intense_human cooperation 
